\title{
In Search of Alternative Research Methods in Marketing: Insights from Layder's Adaptive Theory Methodology
}

\author{
Chandana Rathnasiri Hewege \\ Swinburne University \\ E-Mail: rathnasirichan@yahoo.com \\ Liyanage Chamila Roshani Perera \\ Melbourbe Bussiness School \\ E-Mail: chamilaroshini2004@yahoo.com
}

\begin{abstract}
This paper argues that Layder's adaptive theory methodology can overcome two main methodological issues affecting academic marketing research-namely, (1) paradigm dilemmas caused by the mixed methods approach and (2) apparent imbalance between agency (individual subjectivity) and structure (social structure). A review of research methods used in marketing reveals that quantitative methods continue to dominate. Marketing phenomena tend to arise in the social world through a circular process whereby individual behaviours create social structures that in turn influence individual behaviours. Both the structure and agency perspectives need to be studied in a single research project to fully understand a marketing phenomenon. Adaptive theory, as a sound alternative to positivistic research approach, can achieve a balance between agency and structure perspectives that underpin marketing phenomena.
\end{abstract}

Keywords: Academic Marketing Research Methodology, Adaptive Theory, AgencyStructure Issue

\section{INTRODUCTION}

Almost three decades ago, the issue of overreliance on hypothetico-deductive, quantitative research methods in academic marketing research was identified; consequently, the need for alternative marketing research methods was emphasised (Deshpande, 1983; Hirschman, 1986). Although Malhotra and Peterson (2001) predicted that there would be an increased use of qualitative research methods in 
academic marketing research, recent research (for example, Hanson \& Grimmer, 2007; Harrison \& Reilly, 2011; Hewege, 2010; Nelder, 2011) has revealed that quantitative research methods are still more commonly used than qualitative research methods and that there has been no significant increase in the use of qualitative research methods in academic marketing research. Although quantiative research methods are known for their rigour in terms of thoery testing and generalizing, they are not considerd versatile in capturing important contextual factors underpinning the marketing pheomena being studied (Hewege, 2010; Vermeulen, 2005). Qualitative research methods are efficient in capturing these contextual factors, yet they have been heavily criticized for the lack of generalizability (Arbnor \& Bjerke, 2008; Creswell, 2008; Onwuegbuzie \& Leech, 2010).

However, many marketing researchers have argued that there is a need for resolving the problem of overreliance on quantitative research methods and for moving towards the combined use of both methods in order to better understand marketing phenomena (for example, Creswell, 2008; Harrison \& Reilly, 2011; Hart, 1987; Ofek, 2010; Walle, 1997). The combined use of quantitative and qualitative research methods is commonly known as mixed methods. It is expected that a mixed methods approach can overcome the drawbacks of using a single method by incorporating the relative advantages of both quantitative and qualitative methods (Harrigan, Ramsey, \& Ibbotson, 2012; Harrison \& Reilly, 2011; Tashakkori \& Teddlie, 2003). Many researchers have used mix methods (Arora, 2011; Bazeley, 2004; Davis, Golicic, \& Boerstler, 2011; Harrigan, et al., 2012; Koller, 2008; Parry, Kupiec-Teahan, \& Rowley, 2012), and this approach has become the third methodological movement (Cameron \& Miller, 2007). However, one of the main issues in mixed methods is that the combination of quantitative and qualitative methods tends to pose inconsistencies in research paradigms that underpin mixed methods research (Bazeley, 2004; Harrison \& Reilly, 2011; Hewege, 2010; Hunt, 1992; Perry, Riege, \& Brown, 1998; Sobh \& Perry, 2006).

Marketing phenomena emanating from social context tend to be influenced by a circular process whereby individual behaviour (human agency) creates social structure, which in turn influences individual behaviour. In order to fully understand a marketing phenomenon, both structure and agency aspects need to be understood in one research project. Positivistic research has been criticised for being overly biased towards structure whereas highly qualitative research has been criticised for its overemphasis on individual subjectivity (human agency) (Ryan, Tähtinen, Vanharanta, \& Mainela, 2012). Given the overrepresentation of quantitative (survey-based) research in marketing, it can be argued that marketing research methods are geared to capture 
structural aspects of a phenomena while neglecting individual subjectivity aspects. The lack of an appropriate balance between structure and agency tend to render findings of academic marketing research that are nowhere near reality.

This paper aims to address these two issues by arguing that Layder's adaptive theory methodology can offer a sound alternative to quantitative research approach in marketing. This paper is organized in five sections. After the introduction section, the second section explores research paradigms that underpin academic marketing research. The third section discusses the agency-structure debate in relation to marketing research methods. In fourth section, Layder's adaptive theory is explained, followed by a set of guidelines for application.

\section{RESEARCH PARADIGMS}

A research paradigm is a common body of beliefs, assumptions and rules that govern research (Kuhn, 1970). It is a basic beliefs system that represents a worldview of individuals, their positions in it and a range of possible relationships to it (Guba \& Lincoln, 1994, p. 105). It is also an overall conceptual framework that guides the researcher (Sobh \& Perry, 2006). According to Guba and Lincoln (1994), four common research paradigms - namely, positivism, realism, critical theory, and constructivism — can be identified. A paradigm rests on three assumptions: (1) ontology, (2) epistemology, and (3) methodology (Arbnor \& Bjerke, 2008; Guba, 1990; Guba \& Lincoln, 1994).

Ontology relates to the basic assumptions about the nature of 'reality' in the world. Researchers might have different assumptions about the form and nature of reality (Arbnor \& Bjerke, 2008). For example, whilst positivists believe that reality exists out there driven by natural laws and is apprehensible, constructivists believe that reality is apprehensible in the form of multiple, intangible mental constructs (Guba \& Lincoln, 1994). The relationship between reality and a researcher is referred to as epistemology. For example, a positivist researcher is an objectivist who conducts an independent inquiry into a phenomenon avoiding interferences of his/her values or biases in the phenomenon being studied. On the other hand, a constructivist is a subjectivist who continuously interacts with a phenomenon being studied considering his/her values as important elements of the research process (Arbnor \& Bjerke, 2008; Guba \& Lincoln, 1994). Methodology refers to various methods that a researcher uses to understand reality. In general, positivist researchers mainly use methods that are quantitative and useful in verifying hypotheses (for example, experiments and surveys). In contrast, constructivist researchers use qualitative, hermeneutical, and dialectical methods (Arbnor \& Bjerke, 2008). Understanding researchers' 
philosophical assumptions is important as they help justify and develop suitable research designs (Easterby-Smith, Thorpe, \& Lowe, 2002).

In practice, marketing research is a critical part of the management decisionmaking system (Aaker, Kumar, \& Day, 2009) whereas, in academic terms, it is more about various forms of marketing theory testing (Deshpande, 1983; Hanson \& Grimmer, 2007). Our paper focuses on the latter. As previously mentioned, quantitative research methods based on a positivistic paradigm are common in academic marketing research (Hanson \& Grimmer, 2007; Harrison \& Reilly, 2011; Marsden \& Littler, 1996). In line with positivistic research paradigm, marketing researchers tend to assume that marketers are objective observers whereas consumers are passive subjects (Marsden \& Littler, 1996).

\section{TRENDS IN ACADEMIC MARKETING RESEARCH METHODS}

Qualitative research methods such as in-depth interviews, participant observations, ethnography, and others are not common in academic marketing research (Hanson \& Grimmer, 2007; Hirschman, 1986; Hooper, 2011). Instead, the use of research methods such as experiments, surveys, and other hypothetico-deductive, quantitative methods are common. Marketing researchers tend to borrow models, tools, and techniques from other sciences, such as statistics and economics (Carroll \& Green, 1995). Based on a content analysis of 1,195 articles published in reputed marketing journals, Hanson and Grimmer (2007) found that 24.80 per cent of articles used qualitiatve methods whereas 46.28 per cent used quantitiave methods. Recent research confirmed that this trend continues to prevail (Harrison \& Reilly, 2011), demonstrating that quantitive methods are still popular among marketing researchers.

Deshpande (1983) argued that marketing research tends to rely excessively on quantitative theory-testing methods (hypothesis testing) rather than qualitative theoryconstruction methods; therefore, there is a need to strike a balance between theory testing and construction using methodological triangulation. In support of this notion, Hirschman (1986) further argued that marketing should be viewed as a socially constructed phenomenon and, therefore, qualitative research methods should be employed by marketing researchers. Almost three decades after these observations were made, the debate continues (for example: Harrison \& Reilly, 2011; Nuttall, Shankar, \& Beverland, 2011; Yoo, Lee, \& Bai, 2011). Currently, the trend is to use triangulated, mixed research methods, known as the third research methodological movement (Creswell, 2008; Johnson \& Onwuegbuzie, 2004; Koller, 2008; Tashakkori \& Teddlie, 2003). Researchers tend to triangulate or use a mix of research methods in order to minimise the inherent weaknesses of each method, although this often does 
not resolve agency-structure imbalance. Moreover, mixing quantitative and qualitative research methods without logical explanations might result in paradigm wars (Cameron \& Miller, 2007; Carter, Sanders, \& Dong, 2008; Guba \& Lincoln, 1994).

\section{MISSING LINK: STRUCTURE AND AGENCY DEBATE}

Research approaches that aim to investigate social phenomena can be viewed as taking either an agency or structural approach (Waters, 1994). Agency relates to a research approach focusing on human subjectivity, often at an individual level within a defined boundary and context (Van Gramberg, 2006). At the organisational level, agency refers to an individual's subjectivity relating to aspects of work in the organisation. Agency-level investigations focus on an individual's social actions and reasoning, including the individual's experience within the inter-subjective world (Van Gramberg, 2006). Agency research falls into the interpretive category of analysis, which considers social actions as an inter-subjective phenomenon shaping people's productive capacity (A. Giddens, 1994). Phenomenology and ethnography fall in line with this approach. However, it has been argued that relying solely on agency approach poses a risk of reducing rich social actions to an atomistic level or a microrealm of subjective experience of social actors (Layder, 1997). It might also lead to the development of idiosyncratic theories (Eisenhardt, 1989).

The structural approach, the other major approach to social research, focuses on social structure and its effects on social actors. Social structure refers to relatively enduring institutionalised relationships between social positions and practices located at different levels of the social strata (A. Giddens, 1994). In other words, it is a collective social phenomenon involving economic, political, and social factors (Van Gramberg, 2006). Social theories such as theories of wealth and power, social and cultural anthropology, symbolism, and mass communication are used to assess the nature of the structure affecting an individual or a group of individuals (Van Gramberg, 2006). Conclusions are often drawn from data as the operation of the structure is not directly observable. Most of the survey-based quantitative studies have been criticised for their overreliance on structural aspects (Layder, 1998). Local experience or the agency-level phenomena are neglected and, for this reason, the structural research approach has been criticised (Glaser \& Strauss, 1967).

The main criticism of agency research is that it neglects the social structure and heavily relies on individual subjectivity whereas structural research has been criticised for its neglect of local experience of individuals (Glaser \& Strauss, 1967; Van Gramberg, 2006). Most of the qualitative approaches that have been put forward as an alternative to positivistic research approach have faced at least three challenges 
(Carlsson, 2005). First, some research based on approaches such as grounded theory and ethnography has become mere reportages and local narratives. Second, overreliance on agency or individual experiences has led to the neglect of a macro or wider social structure. Third, the integration and combination of different approaches rooted in different and incompatible ontologies have created ontological issues (such as combining qualitative and quantitative methods for the sake of having a mixed approach). Therefore, it is prudent to select an approach that can minimise these limitations.

Research that captures both agency (individual behaviour and interactions) and structure together in a single approach creates a link between 'human activity and its social contexts' (Layder, 1994, p. 5). Mixed methods research in marketing does not necessarily address the missing link between agency and structure. Furthermore, there is no specific research paradigm that guides mixed method research. Therefore, it is necessary to seek an alternative methodological approach that connects social structures with individual subjectivity.

\section{Critical Realism}

Critical realism (Bhaskar, 1978, 1989, 1998) was developed as an alternative to traditional positivistic research approaches as well as an alternative to non-positivistic (post-positivistic or post-modern) approaches in social sciences (Carlsson, 2005; Ryan, et al., 2012; Wynn \& Williams, 2012). Specifically, it is claimed that critical realism is capable of overcoming the structure-agency linkage problem by offering a way to explain the interplay between structure and agency in organisations (Bhaskar, 1979). It is argued that the problems associated with many qualitative approaches are resolved through critical realism that offers a philosophical tool to understand the reality of natural order and the events and discourses of the social world (Carlsson, 2005). It is believed that understanding and then changing the social world is possible only by identifying the social structures and mechanisms that generate events and discourses (Bhaskar, 1989). According to this method, it is believed that social structures preexist the social actions that reproduce and transform them (A. Giddens, 1976). These structures are supposed to create extant limits within which social interactions take place. Social structures are not spontaneously apparent in the observable pattern of events created by organisational participants, and they can only be identified through the practical and theoretical work of social sciences (Bhaskar, 1989).

When understanding a social reality related to marketing phenomena, three important domains must be considered: the real, the actual, and the empirical (Bhaskar, 1978). The real domain consists of layers: (1) underlying structures and 
generative mechanisms, (2) events and behaviours, and (3) experiences (see Table 1).

Table 1 Elements of Critical Realism

\begin{tabular}{lll}
\hline Domain of Real & Domain of Actual & Domain of Empirical \\
\hline $\begin{array}{l}\text { Structures, Mechanisms and } \\
\text { Relations }\end{array}$ & & \\
\hline Events and behaviours & Events and behaviours & \\
\hline Experiences & Experiences & Experiences \\
\hline
\end{tabular}

The real world is stratified into structures and hence consists of multiple layers. These layers (structures), called generative mechanisms, generate events that occur and do not occur. Bhasker (1979) argued that the social actors operating within the social structures derive power from unequally distributed resources, based on their institutionalised positions and practices. Social relations are reproduced and transformed by these multi-layered social practices and positions (Layder, 1994). Relationships among different social structures tend to generate specific social behaviours and events. These relationships are termed generative mechanisms that can produce social (marketing) events. The actual domain consists of these events and behaviours. In other words, the occurrences of these events and behaviours are observed in the actual domain. Our experiences of these events and behaviours tend to reside in the empirical domain. Interestingly, in our organisational world, social structures in the real domain tend to exist independently of actual patterns of events (Bhaskar, 1978). As a result, the actual pattern of events appears to be out of phase with the social structures. For this reason, researchers need to experiment and make sense of these events and behaviours. Not all events are experienced by the people, meaning that it is possible that events could occur independently of experiences. Thus, real, actual, and empirical domains in the social (organisational) reality are distinct (Bhaskar, 1978). When this idea is projected onto organisations, it is possible to view them as enduring forms that are maintained and transformed through the engagement of positions and practices at different levels of social organisation (Reed, 1997).

\section{LAYDER'S ADAPTIVE THEORY AS A METHODOLOGICAL APPROACH IN MARKETING RESEARCH}

Layder (1994; 1998) developed adaptive theory by incorporating the principles of critical realism for primarily constructing and elaborating theory in conjunction with ongoing empirical research. Layder combined both agency and structure together in a single approach, creating a link between 'human activity and its social contexts' 
(Layder, 1994, p. 5). Through this link, it is envisaged to combine the use of preexisting theory with theory generated from data analysis (Ryan et al., 2012; Wynn \& Williams, 2012). According to Layder, a central feature of realism is its attempt to preserve a 'scientific' attitude towards social analysis while simultaneously recognising the importance of actors' meanings and in some way incorporating them into research (Ryan et al., 2012). Thus, a key aspect of the realist approach is a concern with causality and the identification of causal mechanisms in social phenomena in a manner quite unlike the traditional positivist search for causal generalisations (Layder, 1994).

Adaptive theory suggests a layered framework of human action within social organisation. This framework consists of structural and institutional phenomena (structure), behaviour, and interaction (agency). These layers can be described as context, setting, situated activity, and self (Layder, 1994). Table 2 depicts these layers through an illustrative example.

The context signifies the macro structure that can be examined by using extant social theories pertaining to the investigative domain of the research phenomenon. Table 2 illustrates a set of extant theories that can be used to investigate personality types and the level of customer orientation. The setting focuses on the immediate forms of social organisation, providing the immediate arena for social activities (Carlsson, 2005). For example, setting might relate to the customer-orientation practices related to the organisation or to the group of people under investigation. The situated activities tend to condition, shape, or reshape the social interactions of the actors (employees and managers). For example, an employee's or a manager's reaction to a customer complaint can be assumed to be influenced by the social interaction through these situated activities. The self refers to the individual's relationship to his or her social environment and is characterised by the intersection of biographical experiences and social involvements (Layder, 1994). The area of self covers how employees and managers are affected and respond to certain social processes whereas situated activity focuses on the nature of the social involvement and interactions (Carlsson, 2005; Ryan et al., 2012).

The advantages of adaptive theory as a social research method have often been put forward in comparison with grounded theory (Glaser \& Strauss, 1967), which was introduced to overcome the problems of overreliance on structural research (survey based, positivistic) during the late 1960s (Van Gramberg, 2006). Grounded theory is an approach to the analysis of qualitative data aimed at generating theory from the field data. One of the weaknesses of grounded theory is its overreliance on micro phenomena or agency. In Layder's terms, 'the very fixity of this concentration is a 
factor which prevents grounded theory from attending to historical matters of macro structure as a means of enriching contemporary or present-centred forms of research on micro phenomena' (Layder, 1994, p. 68). As such, in marketing research, grounded theory is insufficient for unearthing the intricate relationship between present-centred agency data and the historically associated structural factors. Another weakness in grounded theory is its incapacity to handle power dynamics in organisations due to its overreliance on situated and interpersonal aspects. Thus, a researcher using grounded theory will most likely omit the significance of the 'behind the scenes' power of situated activities (Carlsson, 2005).

\section{Table 2 An illustration of the Layered Framework}

An illustrative Research Problem: What is the nature of relationship between customer orientation level and personality types of customer service employees?

\begin{tabular}{|c|c|c|}
\hline Element & Focus & Methodological Steps \\
\hline Context & $\begin{array}{l}\text { Extant Structures: To understand } \\
\text { about the structure relating to } \\
\text { customer orientation and } \\
\text { personality types, theories of social } \\
\text { and cultural anthropology, } \\
\text { psychology (theories of } \\
\text { personality), Industrial economics } \\
\text { and, service quality may be used. } \\
\text { Apart from social theories, survey } \\
\text { findings can also be used to inform } \\
\text { the structure. }\end{array}$ & $\begin{array}{l}\text { A literature review needs to be performed in order to develop } \\
\text { a tentative theoretical framework. This framework can assist } \\
\text { the researcher in deciding what data to be collected or what } \\
\text { questions to be asked from the respondents. As and when } \\
\text { data is collected, these theories need to be consulted to make } \\
\text { sense of data emerging from the field. Sometimes, it is } \\
\text { necessary to seek for additional theories. }\end{array}$ \\
\hline Setting & $\begin{array}{l}\text { Immediate environment of social } \\
\text { activity: } \\
\text { This relates to the customer } \\
\text { orientation practices related to the } \\
\text { organisation or to the group of } \\
\text { people under investigation. }\end{array}$ & \multirow{3}{*}{$\begin{array}{l}\text { Setting means the organisation or the entity within which } \\
\text { empirical investigation is to be conducted. It may be a case } \\
\text { study or a group of organisations or people. } \\
\text { In-depth interviews, focus group interviews, observation or } \\
\text { ethnographic data collection method can be used to gather } \\
\text { data on individual subjectivity. At the end of each day of } \\
\text { field work, field notes need to be evaluated in conjunction } \\
\text { with social theories in order to make sense of data (specially } \\
\text { to identify emerging concepts). } \\
\text { During data analysis, two important things can occur at the } \\
\text { same time, i.e. theories are used to understand emerging } \\
\text { concepts (theory) and these emerging theories adapt and } \\
\text { change the theoretical framework. } \\
\text { simultaneous visiting and revisiting to and from data and } \\
\text { theory facilitate a link between agency and structure }\end{array}$} \\
\hline $\begin{array}{l}\text { Situated } \\
\text { activity }\end{array}$ & $\begin{array}{l}\text { Dynamics of social interaction: } \\
\text { This relates to the influence of } \\
\text { social norms, culture, } \\
\text { institutionalised practices on } \\
\text { customer orientation level of an } \\
\text { employee }\end{array}$ & \\
\hline Self & $\begin{array}{l}\text { This relates to the biographical or } \\
\text { individual experiences of } \\
\text { employees or managers. }\end{array}$ & \\
\hline
\end{tabular}

Source: Adapted from Layder, D. 1994. Understanding social theory. London: Sage 
Adaptive theory uses both inductive and deductive procedures for developing and elaborating theory (Layder, 1998). In adaptive theory, both of these theory generation mechanisms occur within the same frame of reference and within the same research project and timeframe, thereby resulting in a more informed analysis and a better understanding of reality pertaining to marketing phenomena. The use of social theories to inform the underlying social structures behind social actions (agency) could improve the quality of the findings of marketing research. Adaptive theory takes a balanced approach, avoiding the pitfalls of being extremely inductive (for example, grounded theory) or deductive (for example, survey-based positivistic research). Ontologically, adaptive theory embraces both objectivism and subjectivism (Layder, 1998). This clears most of the ontological dilemmas found in other research methods that combine different approaches rooted in different ontologies (for example, the survey method is based on objective ontology whereas observation and in-depth interviews are based on subjective ontology).

\section{GUIDELINES FOR APPLICATION}

By using a hypothetical research project as an example, this section explains the step-by-step guidelines for the application of adaptive theory research methodology.

\section{Aim of the Research Project}

The aim is to investigate the relationship between customer-orientation level and personality types of customer service employees who are Chinese migrants to Australia. Figure 1 outlines major methodological steps applied in this research.

\section{Demarcation of the Investigative Domain}

It is advisable to initially demarcate the broad area of the discipline or the study context within which a research problem will be formulated. Familiarisation with current literature related to the study area is certainly helpful.

Illustration: The broad areas of the study could be the customer-orientation level of employees, their personality traits, and the socio-cultural dynamics of Chinese migrant families.

\section{Formulation of Research Problem and Research Questions}

Once the researcher has demarcated the investigative domain of the study, the main research problem and the supporting research questions need to be developed.

\section{Illustration:}

Research Problem: 
Do personality types influence the customer-orientation level of customer service employees?

Research Questions:

1. What personality types are associated with higher levels of customer orientation?

2. How do Chinese family values influence employees' customer service level?

3. How does the interaction between the Chinese family values and Australian work ethic influence employees’ customer orientation levels?

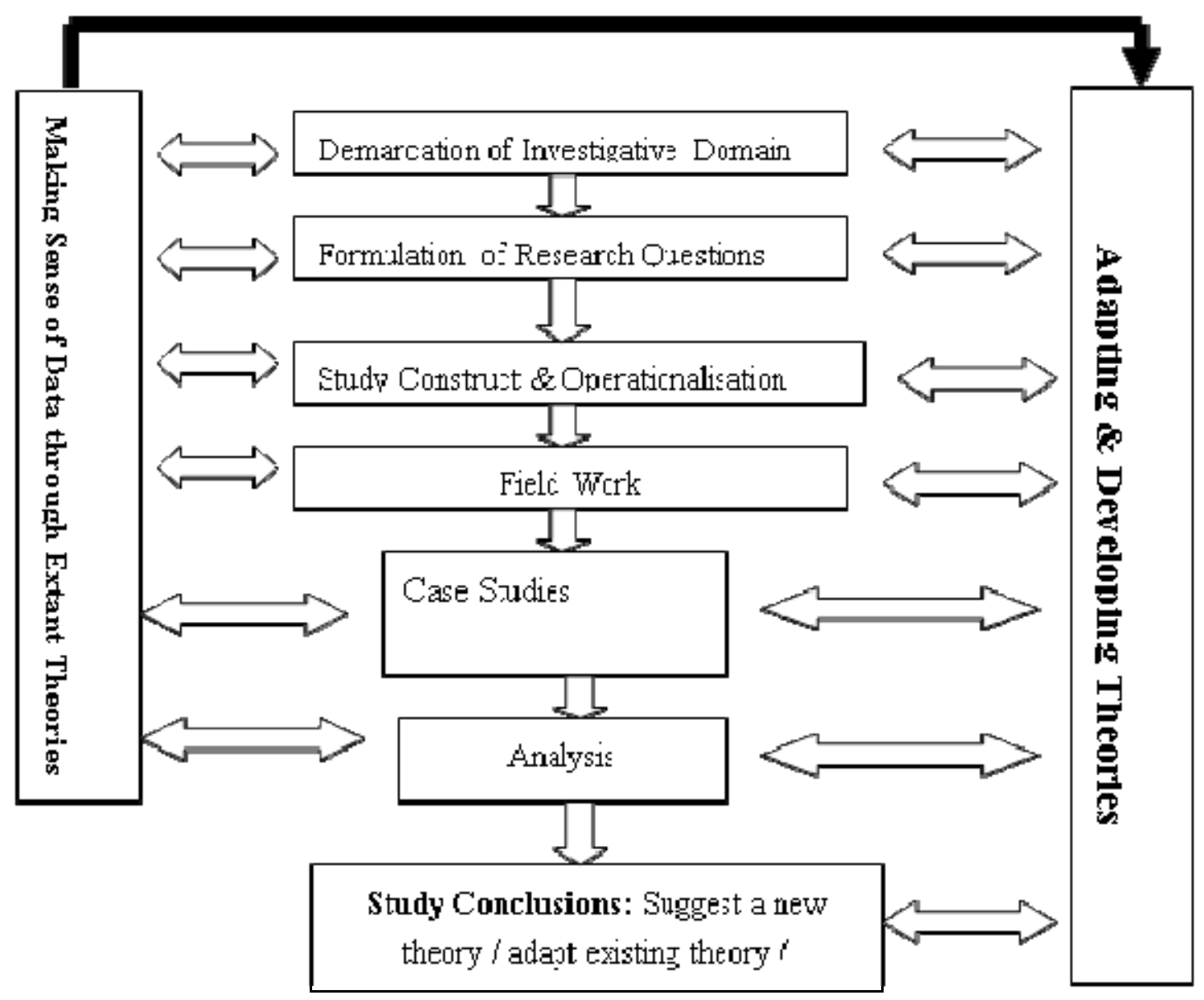

Figure 1 Major Methodological Steps

\section{Developing and Operationalising the Theoretical Framework}

Unlike in other methodological approaches, adaptive theory methodology requires the continuous visiting and revisiting of social theories to make sense of the data. Social theories relevant for a particular research phenomenon could be middle range or overarching social theories that can be used to shed light on the research issue under investigation. When the initial literature review is conducted during the problem 
formulation stage, a 'soft' or 'skeletal' theoretical framework needs to be developed. This tentative theoretical framework is by no means conclusive. The main purpose of this framework is to guide the researcher in deciding the nature of data to be collected (what to seek for) and to make sense of the data emerging from the field. As and when data emerges, this theoretical framework can be adapted or changed. As shown in Figure 1, the theoretical framework will be shaped and reshaped during the whole period between problem formulation and the completion of data analysis.

The theoretical framework can be informed by extant theories from disciplines such as psychology (personality theories), marketing (customer orientation, internal marketing), and anthropology (cultural assimilation). The way in which generative mechanisms work can be understood by referring to these extant theories. These theories inform about diverse social structures and varying power relations that tend to generate events and behaviours. Data gathered from employees, managers, and other relevant actors can be interpreted in alignment with the extant theories. The data will inform the researcher of events and behaviours generated by the varying social relations among different groups. As previously explained, a complete understanding of the research phenomena can be achieved by combining all three domains-actual, real, and empirical—by twining extant theories with data.

\section{Field Work}

Adaptive theory enables a researcher to select one or many data collection methods that include in-depth interviews, focus groups, observations, surveys, and perusal of other secondary sources such as company documents, reports, legislation, government reports, and media publications. It is also possible to have a combination of a primary and a secondary method. For example, the primary method of data collection could be in-depth interviews and spontaneous observations whereas the secondary methods could be a survey and perusal of company documents and reports, relevant legislation, and government reports as well as a review of the relevant media publications.

At the end of each interview and at the end of each day of field work, notes should be taken and reviewed together with reflective practices, thereby interpreting data in terms of social theories. Continuous cross-reference to and consultation of social theories need to be administered as an important element of the reflective practices. Apart from interviews, as previously mentioned, it is also possible to observe the behaviour of organisational participants each time the organisation or the site is visited by the researcher. These observation data can be added to the daily 
memos (notes) and combined with the interview data. In addition, company publications such as monthly bulletins, annual reports, and circulars can be used to validate the interview data to enhance the quality of data triangulation. Other sources such as media reports can be used to gather additional data and to validate interview data.

\section{Analysis}

It is recommended that a qualitative data analysis software package such as Nvivo be used. Such software offers powerful tools to manage a large quantum of qualitative data effectively and efficiently. However, it should be noted that manual data analysis, when properly conducted, is by no means inferior to computer-aided analysis. Data analysis in terms of adaptive theory requires creating themes from the interview responses (Van Gramberg, 2006). The presence of these recurrent themes forms the foundation of the emerging themes (Layder, 1998) and can be identified by tagging them with identifiable codes based on their indication of a concept (Layder, 1998). A typical set of data analysis steps is as follows:

1. Completion of daily field notes

2. Summary of field notes and development of memos in consultation with social theories (reflection)

3. Identification of emerging themes in line with research questions of the study (coding)

4. Grouping of similar themes into concepts

5. Assessment of these concepts in relation to social theories used in the study

6. Development of a new theory or adaptation to the existing theory

\section{CONCLUSION}

Adaptive theory takes a balanced approach, avoiding the pitfalls of being an extremely deductive (for example, survey-based positivistic research) or inductive (for example, grounded theory based on in-depth interviews) approach. The use of social theories to inform the underlying social structures behind social actions (agency) could improve the quality of the findings of academic marketing research, thereby resolving most of the paradigm dilemmas found in mixed method research that combine different approaches rooted in different paradigms (for example, the survey method is based on objective ontology whereas observations and in-depth interviews are based on subjective ontology).

This paper has noted that, although there is a recurrent appearance of positivistic 
research paradigm, there is also a growing trend in academic marketing research inclined to use mixed methods. Some argue that the use of mixed methods trades off the inherent weaknesses of using a single method. However, the debate pertaining to inconsistencies in mixed method research paradigm seems to have continued. More importantly, most research methods suffer from inherent weaknesses of focusing only on either the social actor perspective (agency) or the social structure perspective. An alternative methodological approach derived from Layder's adaptive theory was proposed. Finally, it was shown that adaptive theory can resolve the two common issues in academic marketing research: (1) paradigm dilemmas caused by mixed methods approach and (2) the apparent imbalance between agency and structure related to marketing research methods.

\section{REFERENCES}

Aaker, D. A., Kumar, V., \& Day, G. S. (2009). Increasing the Effectiveness of Marketing Research. California Management Review, 23(2), 59. http://dx.doi.org/10.2307/41164918

Arbnor, I., \& Bjerke, B. (2008). Methodology for creating business knowledge. London, England: Sage Publications.

Arora, R. (2011). Bundling or unbundling frequently purchased products: a mixed method approach. Journal of Consumer Marketing, 28(1), 67-75. http://dx.doi.org/10.1108/07363761111101967

Bazeley, P. (2004). Issues in mixing qualitative and quantitative approaches to research. Applying Qualitative Methods to Marketing Management Research, 141-156.

Bhaskar, R. (1978). A realist theory of science. Sussex, England: Harvester Press.

Bhaskar, R. (1989). Reclaiming reality. London, England: Verso.

Bhaskar, R. (1998). The Possibility of Naturalism ( $3^{\text {rd }}$ ed.). London, England: Routledge.

Cameron, R \& Miller, P (2007, December). Mixed methods research: phoenix of the paradigm wars. In R. Chapman (Ed.) Managing our intellectual and social capital : Proceedings of the 21st ANZAM Conference. Sydney, Australia: Promaco.

Carlsson, S. A. (Ed.). (2005). Critical Realism in IS Research. In M. Khosrow-Pour (Ed.), Encyclopedia of Information Science and Technology (pp. 611-616). Hershey, PA: Information Science Reference. http://dx.doi.org/10.4018/978-159140-553-5.ch108 
Carroll, J. D., \& Green, P. E. (1995). Guest editorial: Psychometric Methods in Marketing Research: Part I, Conjoint Analysis. Journal of marketing Research, 32(4), 385-391. http://dx.doi.org/10.2307/3152174

Carter, C. R., Sanders, N. R., \& Dong, Y. (2008). Paradigms, revolutions, and tipping points: The need for using multiple methodologies within the field of supply chain management. Journal of Operations Management, 26(6), 693-696. http://dx.doi.org/10.1016/j.jom.2008.07.002

Creswell, J. W. (2008). Research design: Qualitative, quantitative, and mixed methods approaches. Thousand Oaks, CA: Sage Publications.

Davis, D. F., Golicic, S. L., \& Boerstler, C. N. (2011). Benefits and challenges of conducting multiple methods research in marketing. Journal of the Academy of Marketing Science, 39(3), 467-479. http://dx.doi.org/10.1007/s11747-010-0204-7

Deshpande, R. (1983). "Paradigms Lost": On Theory and Method in Research in Marketing. The Journal of Marketing, 47(4), 101-110. http://dx.doi.org/10.2307/1251403

Easterby-Smith, M., Thorpe, R., \& Lowe, A. (2002). Management research: An introduction. London , England: Sage Publicationss.

Eisenhardt, K. M. (1989). Building Theories from Case Study Research. The Academy of Management Review, 14(4), 532-550. http://dx.doi.org/10.2307/258557

Giddens, A. (1976). New rules of sociological analysis. London, England: Hutchinson \& Co.

Giddens, A. (1994). The Constitution of Society. Cambridge, England: Polity Press.

Glaser, B. G., \& Strauss, A. C. (1967). The discovery of grounded theory: strategies for qualitative research. New York, NY: Aldine Publishing Co.

Guba, E. G. (1990). The paradigm dialog. Newbury Park, CA: Sage Publicationss. http://dx.doi.org/10.1177/104973239600600407

Guba, E. G., \& Lincoln, Y. S. (1994). Competing paradigms in qualitative research. Handbook of qualitative research (pp. 163-194). London, England: Sage Publicationss.

Hanson, D., \& Grimmer, M. (2007). The mix of qualitative and quantitative research in major marketing journals, 1993-2002. European Journal of Marketing, 41(1/2), 58-70. http://dx.doi.org/10.1108/03090560710718111

Harrigan, P., Ramsey, E., \& Ibbotson, P. (2012). Exploring and explaining SME marketing: investigating e-CRM using a mixed methods approach. Journal of Strategic Marketing, 20(2), 127-163. http://dx.doi.org/ 10.1080/0965254x.2011.606911 
Harrison, R. L., \& Reilly, T. M. (2011). Mixed methods designs in marketing research. Qualitative Market Research: An International Journal, 14(1), 7-26. http://dx.doi.org/10.1108/13522751111099300

Hart, S. (1987). The use of the survey in industrial market research. Journal of Marketing Management, 3(1), 25-38. http://dx.doi.org/10.1080/0267257X.1987.9964025

Hewege, C. R. (2011, December). Resolving structure--agency dichotomy in management research: Case for adaptive theory research methodology. Paper presented at the 24th Annual Australian and New Zealand Academy of Management Conference, North Terrace, Australia.

Hirschman, E. C. (1986). Humanistic inquiry in marketing research: philosophy, method, and criteria. Journal of marketing Research, 23(3), 237-249. http://dx.doi.org/10.2307/3151482

Hooper, C. S. (2011). Qualitative In Context. Journal of Advertising Research, 51, 153-166.

Hunt, S. D. (1992). For reason and realism in marketing. The Journal of Marketing, 56(2), 89-102. http://dx.doi.org/10.2307/1252045

Johnson, R. B., \& Onwuegbuzie, A. J. (2004). Mixed methods research: A research paradigm whose time has come. Educational researcher, 33(7), 14-26. http://dx.doi.org/10.3102/0013189X033007014

Koller, M. (2008). A Future research agenda for mixed-method-design in business research. International Journal of Business Research, 8(4), 50-60.

Kuhn, T. S. (1970). The structure of scientific revolutions. Chicago, IL: University of Chicago Press.

Layder, D. (1994). Understanding social theory. London, England: Sage Publicationss.

Layder, D. (1997). Modern sociological theory: key debates and new directions London, England: UCL Press.

Layder, D. (1998). Sociological practice: Linking theory and social research London, England: Sage Publicationss.

Malhotra, N. K., \& Peterson, M. (2001). Marketing research in the new millennium: emerging issues and trends. Marketing Intelligence \& Planning, 19(4), 216-235. http://dx.doi.org/10.1108/EUM0000000005560

Marsden, D., \& Littler, D. (1996). Evaluating alternative research paradigms: a market-oriented framework. Journal of Marketing Management, 12(7), 645-655. http://dx.doi.org/10.1080/0267257X.1996.9964442 
Nelder, J. (2011). Quantitative In Context. Journal of Advertising Research, 51, 204206.

Nuttall, P., Shankar, A., \& Beverland, M. B. (2011). Mapping the Unarticulated Potential of Qualitative Research. Journal of Advertising Research, 51(1), 153163. http://dx.doi.org/10.2501/JAR-51-1-153-166

Ofek, E. (2010). Marketing and Innovation Management: An Integrated Perspective. Foundations and Trends in Marketing, 4(2), 77-128. http://dx.doi.org/10.1561/1700000020

Onwuegbuzie, A. J., \& Leech, N. L. (2010). Generalization practices in qualitative research: a mixed methods case study. Quality \& Quantity, 44(5), 881-892. http://dx.doi.org/10.1007/s11135-009-9241-z

Parry, S., Kupiec-Teahan, B., \& Rowley, J. (2012). Exploring marketing and relationships in software SMEsA mixed methods approach. Management Research Review, 35(1), 52-68. http://dx.doi.org/10.1108/01409171211190805

Perry, C., Riege, A., \& Brown, L. (1998, November). Realism rules OK: Scientific paradigms in marketing research about networks. Paper presented at the 1998 Annual Australian and New Zealand Academy of Management Conference. Dunedin, New Zealand: University of Otago. Retrieved from http://www.anzmac.org/conference/1998/Cd_rom/Perry73.pdf

Reed, M. I. (1997). In Praise of Duality and Dualism. Rethinking Agency and Structure in Organisational Analysis. Organisational Studies, 18(1), 21-42. http://dx.doi.org/10.1177/017084069701800103

Ryan, A., Tähtinen, J., Vanharanta, M., \& Mainela, T. (2012). Putting critical realism to work in the study of business relationship processes. Industrial Marketing Management, 41(2), 300-311. $\quad$ http://dx.doi.org/ 10.1016/j.indmarman.2012.01.011

Sobh, R., \& Perry, C. (2006). Research design and data analysis in realism research. European journal of Marketing, 40(11/12), 1194-1209. http://dx.doi.org/10.1108/03090560610702777

Tashakkori, A., \& Teddlie, C. (2003). Major issues and controversies in the use of mixed methods in the social and behavioral sciences. Handbook of mixed methods in social and behavioral research (pp. 3-50). Thousand Oaks, CA: Sage Publications.

Van Gramberg, B. (2006). 'The case for adaptive theory for investigating meaning in the workplace' Management: Pragmatism, Philosophy, Priorities, 19th Conference of the Australia and New Zealand Academy of Management, Rockhampton, 6-9 December. 
Vermeulen, F. (2005). On rigour and relevance: Fostering dialectic progress in management research. Academy of Management Journal, 48(6), 978-982. http://dx.doi.org/10.5465/AMJ.2005.19573102

Walle, A. H. (1997). Quantitative versus qualitative tourism research. Annals of Tourism Research, 24(3), 524-536. http://dx.doi.org/10.1016/S01607383(96)00055-2

Waters, M. (1994). Modern Sociological Theory. London, England: Sage Publicationss.

Wynn, J. D., \& Williams, C. K. (2012). Principles for conducting critical realist case study research in information systems. MIS Quarterly, 36(3), 787-810.

Yoo, M., Lee, S., \& Bai, B. (2011). Hospitality marketing research from 2000 to 2009: Topics, methods, and trends. International Journal of Contemporary Hospitality Management, 23(4), 517-532. http://dx.doi.org/10.1108/09596111111130010 